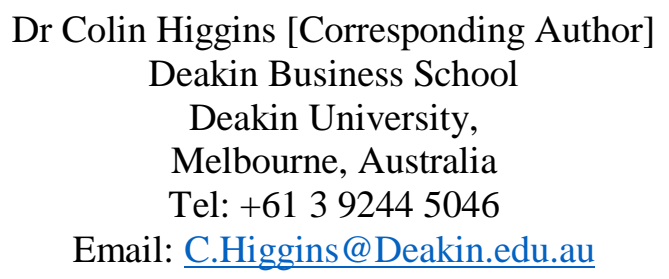

\author{
Dr Wendy Stubbs \\ School of Social Science \\ Monash University, \\ Melbourne, Australia \\ Tel: +61 399052915 \\ Email: Wendy.Stubbs@Monash.edu \\ Professor Markus Milne \\ Department of Accounting and Information Systems \\ University of Canterbury, \\ Christchurch, New Zealand \\ Tel: +64 33642624 \\ Email: Markus.Milne@Canterbury.ac.nz
}

Keywords: Australia, institutional theory, issues-based fields, non-reporters, sustainability reporting

Forthcoming in Journal of Business Ethics

This study was approved by the Deakin University Human Ethics Committee and Monash University Human Ethics Committee and have therefore been performed in accordance with the ethical standards laid down in the 1964 Declaration of Helsinki. 


\title{
Is sustainability reporting becoming institutionalised? The role of an issues-based field
}

\begin{abstract}
We study companies that do not produce a sustainability report in contexts where institutionalisation is assumed. Based on a careful analysis of interaction patterns between non-reporting companies, sustainability interest groups, and peer organisations we find patterns of discursive and material isomorphism that suggest sustainability reporting is confined to an issues-based field, rather than spreading as an institutionalised practice across the business community. We argue that the issuesbased field exerts only weak pressure for sustainability reporting, and that encouraging more firms to report rests on understanding what influences companies to interact more widely to become part of this field.
\end{abstract}

In this paper we seek to develop institutional explanations of sustainability reporting, building on observations that institutionalisation is underway and is shaping reporting activity (Barkemeyer, Preuss, \& Lee, 2015; de Villiers \& Alexander, 2014; de Villiers, Low, \& Samkin, 2014; Gürtürk \& Hahn, Forthcoming). However, we refine these observations by investigating the institutional field(s) that deem reporting necessary, and the institutional pressure influencing its practice. We focus on non-reporting firms because, as Choudhury (1988) explains, "the absence of accounting (sic) may tell researchers a lot about the nature of accounting (sic) and its existence" (p. 550). Non-reporters provide a contrast to reporting firms and isolate influences on reporting that are difficult to detect when reporting occurs.

This study is important because sustainability reporting is seen as a way for companies to meet their social and ethical responsibilities toward the environment and the communities in which they operate (Bebbington, 2001; Owen, 2008). However, new insights are needed to encourage more companies to report in ways that lead to meaningful change (Milne \& Gray, 2007). As we explain below, while 
institutional theory offers a new explanation for reporting patterns, studies to date have involved only a basic application of institutional theory, often invoking industry or national level indicators in their analyses or relying on indicators such as common professional qualifications to assert explanations for commonality of practice (Aerts, Cormier, \& Magnan, 2006; Barkemeyer et al., 2015; de Villiers \& Alexander, 2014). A related and recent exception, however, is O'Sullivan and O'Dwyer (2015) who invoke the work of Hoffman (1999) to study the role of an issues based field in the penetration of sustainable finance practices in the international banking industry. Overall, refinements are necessary to fully appreciate the contribution institutional theory can make to understanding sustainability reporting behaviour.

The motivation for this study rests on changing patterns of sustainability reporting, and the concomitant developments in theorising about this practice [see note one]. Reporting patterns have changed substantially over the past few years, but theorising has not kept pace. Early reporters in the 1980s and early 1990s were mostly large, listed firms, subject to social pressure for which reporting was convincingly explained by legitimacy drivers (Deegan, 2002; Deegan, Rankin, \& Tobin, 2002; Deegan, Rankin, \& Voght, 2000; Lindblom, 1993). The profile of reporters has now changed, such that legitimacy is likely to be only one explanation for reporting (Morhardt, 2010). Since the mid to late 1990s sustainability reporting has spread to a wide variety of different companies, with smaller, less-intensive, service-based and less visible companies making up recent growth (Higgins, Milne, \& van Gramberg, 2015). One explanation for changing reporting patterns has been a widening of the business case, beyond legitimacy, to include other benefits of reporting. These include: marketing, improving competitive position; social, warding off stakeholder challenges; political, reducing political pressure and regulation; and accountability where the company is playing its part in sustainability outcomes (Solomon \& Lewis, 2002).

Another explanation draws on institutional theory (Higgins \& Larrinaga, 2014; Larrinaga, 2007). Institutional theorists suggest that sustainability reporting, rather than being purposefully initiated to achieve specific business case outcomes, occurs because managers acquiesce to social pressure that 
renders it 'required', 'expected', or 'normal' in the contexts in which they operate (DiMaggio \& Powell, 1991). The context in which managers operate is understood in terms of the 'field'. Fields include groups and individuals that interact and, by so doing, collectively shape norms and expectations within that context. Within the institutional literature 'fields' are sometimes considered analogous to 'industry', but they may also form in geographical locations, and shape the activities expected in those specific communities. They might also be issues-based, for example, the environment, or occupational health and safety, where those affected collectively define and shape appropriate responses to the issues. Fields can also form around strategies, where organisations positioning themselves similarly, for example, on the basis of quality or sustainability, adopt the same practices such as quality circles or sustainability committees.

What becomes institutionalised, or seen as 'necessary', is not negotiated in a structured way between field members, but results from subtle interactions and 'jockeying' between them (Hardy \& Maguire, 2010; Lounsbury, Ventresca, \& Hirsch, 2003; Phillips, Lawrence, \& Hardy, 2004). Institutional pressures that develop take a variety of forms. Sometimes "the influence of the institutional environment can be subtle, working its way in to the organization through rationalized myths, or directly, coming as an indictment on a felony charge" (Galaskiewicz, 1991, p. 293). Thus institutional pressures can be regulatory, normative or cognitive (Scott, 1995). Regulatory institutional pressures such as rules, regulations, or conditions of membership, exert coercive pressure and influence the adoption of practices because of the potential for reward or threat of punishment (DiMaggio \& Powell, 1983). Normative institutional pressures rest on social consensus within a field about the 'right thing to do' (Scott, 1995, p. 51). Cognitive institutional pressures are the most subtle and influence organisational action because norms and behaviours become taken for granted, such that alternative ways of thinking and acting are not even consciously considered. Managers act because it is 'normal' to do so. The point is that organisational activities, such as sustainability reporting, are not deliberately conceived by managers, but are responses to field-level expectations built up over time through interactions in a field. Managers may not always be aware that their actions are institutionally shaped, but isomorphism ensues (Friedland \& Alford, 1991; Milne \& Patten, 2002). 
Recent studies show that sustainability reporting is becoming institutionalised in a size-based global field (Kolk, 2011), a few geographically-based regional/national fields, some industry-based fields, and in a strategy-based field (Kolk, 2011; Chen \& Bouvain, 2009; Golob \& Bartlett, 2007; Kolk, 2005, 2010a; Young \& Marais, 2012; Herremans, Herschovis, \& Bertels, 2008; Bebbington, Higgins, \& Frame, 2009). The wider sustainability literature, which is increasingly taking an institutional perspective, suggests that 'corporate greening' may be related to the emergence of an 'issues-based' field, so a similar field may shape sustainability reporting (Hoffman, 1999; Hoffman \& Ocasio, 2001). In each field various pressures have been observed, for example, in Australia where cultural norms shape reporting activity, in contrast to Canada where reporting is influenced by normative expectations generated by professional associations (Herremans, Herschovis, \& Bertels, 2008).

Taken at face value, the spread of sustainability reporting is attributable to institutionalisation in multiple fields. However, fields have tended to be assumed from reporting similarities, rather than being identified through analysis of interaction patterns. Reporting has also been seen as acquiescence to institutional pressure, which fails to account for variations within fields. As we show, institutional theory offers new and plausible explanations for reporting. It also potentially provides new opportunities for improving reporting, but more attention needs to be afforded to institutional fields and institutional pressures.

Our aim in this paper is to refine institutional accounts of sustainability reporting. We sought an approach that builds on existing studies but also enables us to focus specifically on institutional influences. We identified 23 Australian companies that do not undertake sustainability reporting, and we undertook in-depth, semi-structured interviews with the managers of these firms. These companies share organisational and strategic characteristics and all operate in fields where existing studies suggest reporting is becoming institutionalised. Our objective is to shed light on the influence of a field(s), and the pressures therein. The specific questions explored in this study are:

1. Is sustainability reporting spreading to multiple institutional fields? 
2. What type of institutional pressure compels managers to report?

In summary, our findings suggest that sustainability reporting is not spreading to multiple institutional fields, but that it is a normal and acceptable part of a relatively contained issues-based field built around a 'middle ground' discourse of sustainability. Within this field it is sustainability rather than sustainability reporting that is institutionalised, and thus the pressure to report is relatively weak. Firms may or may not report because pressure is for 'action' and 'responsiveness', but not for reporting specifically. The main contribution of this study is to re-orient institutional attention away from how sustainability reporting is spreading to offering a more focused analysis of the role of a specific field and how it interacts with other fields in shaping and influencing sustainability reporting practice.

Next, we outline how institutional theory assists in explaining recent reporting patterns, and how it can drive change in reporting practice. We explain the issues associated with field definition and institutional pressures that must be addressed in order to realise the change potential of institutional theory. We then explain why non-reporting firms offer a valuable perspective, and we outline our sample selection, including how we identified non-reporting firms. A detailed results section follows, before we offer a concluding discussion that ties our argument together and points to areas for further research.

\section{Background and Literature Review}

Sustainability reporting is largely seen as desirable (Andersen, 2003; Douglas, 2007). It is viewed as a proxy for a company's engagement with sustainability, it reflects management commitment to improving social and environmental performance, and it has been seen as a way to bring about change in company behaviour ((Bebbington, 1997). To this end, the motivation to understand and theorise company reporting has been, in part, to uncover what might encourage others to report (Adams, 2002). 
Some attribute reporting to organisational characteristics including company size, financial success, 'visionary' founders/chief executives, and an active strategic posture towards sustainability (Adams, 2002; Fifka, 2011). If organisational characteristics that drive reporting can be identified, it may be possible to predict and encourage reporting behaviour (see Adams, 2002). Others attribute reporting to motivations and incentives. As explained previously, these include market, social, political and accountability benefits and suggest that sustainability reporting is attributed to the achievement of a number of outcomes (Solomon \& Lewis, 2002). While some firms are motivated to, for example, influence powerful stakeholders, others seek a symbol of their competitive differentiation as a 'responsible' or 'sustainable' organisation (Bebbington, Higgins, \& Frame, 2009).

Our interest is in institutional explanations of sustainability reporting. Over the past few years, institutional theory has offered new insights in to the adoption of sustainability-related business practices, including how and why they differ within and between countries and contexts (Boxenbaum, 2006). It has started to inform trends about the uptake of sustainability reporting. As explained, institutional theory downplays deliberate management action tied to individual organisational circumstances, and suggests that what managers do rests on norms and expectations in the fields in which they operate. Companies do similar things and provide similar rationales for their actions because they seek to 'fit in' with social expectations.

Recent studies of sustainability reporting show traces of institutionalisation. While reporting is spreading it is doing so in clusters rather than consistently across the business community (Chen \& Bouvain, 2009; Young \& Marais, 2012). These clusters include large global companies (the G250). The triennial surveys of corporate responsibility reporting by KPMG show, for example, that in 2011 95\% of the G250 firms undertook sustainability reporting, up from 79\% in 2008 and 50\% in 2005 (KPMG, 2005, 2008, 2011). These firms all report in similar ways, suggesting a global sustainability reporting field is plausible (Kolk, 2011). Similar observations are made regarding MNCs adoption of other environmental initiatives, in which the largest global companies adopt "a global, cosmopolitan 
orientation that is not tied to any national identity" (Kostova \& Zaheer, 1999, p. 73). Other clusters of reporting are apparent in some countries and regions rather than others, suggesting the institutionalisation of reporting is geographically-based (Chen \& Bouvain, 2009; Golob \& Bartlett, 2007; Kolk, 2005, 2010a; Kolk, Walhain, \& van de Wateringen, 2001; Young \& Marais, 2012). There may also be institutional pressures within industry-based fields, accounting for why reporting is more common in some industries than others (Herremans et al., 2008). Other clusters are observable amongst firms pursuing a 'green' or 'values' form of strategic differentiation pointing to the presence of a strategy-based field and the institutionalisation of reporting within it (Bebbington et al., 2009). Certainly, this has been observed in other studies of why firms 'go green' (Bansal \& Roth, 2000).

Institutionalisation explains why some firms do not report when their characteristics suggest they would. The large firms that do not report and the non-reporting firms that face similar legitimacy challenges to reporting companies may not operate in a field where reporting is expected (Martin \& Hadley, 2008; Milne \& Gray, 2007; Stubbs, Higgins, \& Milne, 2013; Herremans et al., 2008; Quaak, Aalbers, \& Goedee, 2007). Institutional theory also sheds light on why some firms do report, when there is little reason to do so. Small, low-impact, less visible, and service-based reporting companies that do not face legitimacy challenges and are not seeking business-case outcomes tend to operate in fields where reporting is seen as essential. Institutional pressure compels them to act (Higgins et al., 2015).

Clarity is needed, however, about the exact nature of institutional field(s) in which reporting is deemed legitimate and necessary. If firms report because they're part of a field or, conversely, they do not because they are not part of a field, we need a clearer picture of those fields. Field definition is problematic, and it has received only scant attention in reporting studies (Hoffman, 2001; Meyer \& Scott, 1992; White, 1992). Those that make up fields, typically including business organisations, regulators, interest groups, trade associations, professional bodies, social influencers, for example, the media, and sometimes institutional investors, professions, and consulting firms are clear about their 
institutional fields, but the boundaries around them are less clear. It is often the case that institutional interactions that demonstrate their existence.

In his early work, DiMaggio (1991) described fields as being groups and individuals that "collectively constitute a recognised area of institutional life" (p. 148). Scott (1995) suggested that they are made up of diverse groups that "partake of a common meaning system and whose participants interact more frequently and fatefully with one another than with actors outside the field" (Scott, 1995, p. 56). The implications for institutional analysis is that fields cannot be determined a priori on the basis of similarities in practice; they must be analytically detected (Hoffman, 1999). Interactions signal the existence of a field, and fields wield influence because of those interactions. Indeed, as Zeitz, Mittal, and McAuly (1999) suggest, just because something is adopted en masse it is not necessarily institutionalised. An organisational field must be detected by "identifying: an increase in the extent of interaction among organizations in the field; the emergence of sharply defined interorganizational structures of domination and patterns of coalition; an increase in the information load with which organizations in a field must contend; and the development of a mutual awareness among participants in a set of organizations that they are involved in a common enterprise" (DiMaggio \& Powell, 1983, p. 65).

Whether firms do, or do not, report also relates to the extent and nature of institutional pressure that prevails within fields. This has also been over-simplified in reporting studies, such that the type of pressure within fields that gives rise to sustainability reporting is ambiguous. Traditionally, institutional studies assumed simple acquiescence to institutional pressure, but its monolithic nature is overstated and assumptions about acquiescence are simplistic (Barreto \& Baden-Fuller, 2006). Some institutional theorists suggest managers can resist or manipulate institutional pressure (Hoffman, 2001; Oliver, 1991). They can move between fields and change and re-shape institutional pressure (Lawrence, Suddaby, \& Leca, 2011; Maguire, Hardy, \& Lawrence, 2004). Some types of, or combinations of, pressures have more influence than others (Barreto \& Baden-Fuller, 2006). 
While the key tenets of institutional theory are that it is types of pressures that form within fields that shape activity, to make sense of reporting from an institutional perspective these two dimensions of institutionalisation require greater clarity. We consider whether sustainability reporting is, or is becoming, institutionalised in each field outlined above, or if the field needs to be defined in some other way. Close attention to field definition enables a sharper perspective on institutional pressure within the field(s) to be considered. Next, we discuss our study design.

\section{Research Approach and Methods}

To study the field(s) in which sustainability reporting may, or may not, be institutionalised and the types of pressures that cohere within those fields, we selected a research design that would isolate institutional effects. We sought to do so by observing what is different when reporting is absent, amongst companies similar to those that do report. By doing so, our sample provides a revealing contrast to those that are said to be subject to the variety of influences on reporting.

To identify non-reporting companies, we defined a reporting company. We were guided by the Global Reporting Initiative that defines a sustainability report as one that discloses economic, social, and environmental outcomes and results in the context of the organisation's commitments, strategy, and management approach [see note two]. Our definition of non-reporting firms is those that do not fit this criteria. We acknowledge that there are differences in the quality and detail reported by companies, and that this criteria could result in the inclusion of firms that are undertaking some disclosure. Our study, however, is not about why individual companies do not report, or the circumstances at the individual organisational level that give rise to variation between firms. It is an exploration of the fields and pressures that shape reporting and the social norms and pressures that encourage organisations to report. 
We acknowledge that the GRI has a number of limitations, including its ability to disguise unsustainable aspects of company operations (Milne \& Gray, 2013) and that improvement is needed in how it frames sustainability (Archel, Fernández, \& Larrinaga, 2008; Gray \& Bebbington, 2007). Nevertheless, GRI has become the default standard for sustainability reporting (del Mar AlonsoAlmeida, Llach, \& Marimon, 2014). The 2011 KPMG survey, relating to the period of our data collection, reveals that $80 \%$ of the G250 companies and, on average, $69 \%$ of the N100 companies now align to the GRI standards and these proportions have been growing steadily. Further, the GRI definition forms part of major rankings and assessment activities of sustainability reporting in various countries, including Australia. The GRI forms the basis of the annual survey of sustainability reporting practices of the ASX200 companies undertaken by the Australian Council of Superannuation Investors (Australian Council of Superannuation Investors, 2011).

To generate our sample, we searched the websites of the largest 200 companies, by market capitalisation on the Australian Stock Exchange (ASX200), for those that were not reporting. We did not restrict our selection to only printed, stand-alone reports because we recognise that, as reporting has evolved, firms report sustainability information in a variety of ways (Rolland \& Bazzoni, 2009; Tilt, 2008). We focused on whether the information reported conformed to a systematic presentation of sustainability as described above. In July 2011 we found 89 non-reporting firms amongst the top 200 companies. This number is consistent with other assessments of Australian reporting patterns undertaken around the same time (Australian Council of Superannuation Investors, 2011; Higgins et al., 2015; KPMG, 2008).

We categorised the non-reporting firms by industry. Then, because our interest is in exploring institutionalisation as revealed from existing studies of reporting trends, we selected firms in fields where institutionalisation is suggested. (Kolk, 2003, 2007, 2008, 2010b) studies suggest institutionalisation is underway amongst large, listed firms, and the latest KPMG survey shows that $84 \%$ of the top mining companies, $69 \%$ of the largest energy companies, and $61 \%$ of financial services firms all report, and all show increases from the 2008 report. In the other industries, the 
patterns are more variable: $57 \%$ of large gambling firms and about $52 \%$ of retailers report. The proportion of firms in these industries reporting has been steadily increasing, and between the 2008 and 2011 surveys these industries have shown the greatest reporting uptake. Amongst the other nonreporters within the ASX200 there were insufficient cases of non-reporters or reporters to even hypothesise that institutionalisation was occurring, for example, in two pharmaceutical firms where one reported and one did not. We're confident our sample yields a sufficient sweep of non-reporting firms to be meaningful. Our selection produced a list of 44 Australian firms.

We searched the websites of all 44 non-reporting firms for a contact who could discuss the organisation's position on sustainability and reporting. In many cases we contacted the organisation directly to identify the relevant contact. We ended up with a wide cross section of managers who agreed to be interviewed, at the same time encountering a considerable number that refused. Tellingly, some organisations had no one who could answer our questions. The 23 sample firms we studied were spread across Australia, located in Victoria, New South Wales and Western Australia. The respondents, their industry sector, and the positions of the interviewees are detailed in Table One.

\section{Insert Table One}

Our data collection involved in-depth semi-structured interviews that lasted between 45 and 60 minutes. Twenty (20) were completed on the company's premises, and the remaining three were undertaken by telephone. Interviewees were briefed that we were exploring the perspectives of firms that do not receive much attention in the sustainability literature, including studies of sustainability reporting. Our questions sought insights about sustainability in general and reporting in particular. The questions canvassed the manager's understanding of sustainability, the most pressing social and environmental concerns for the organisation, the focus of stakeholder attention they received, and how sustainability-related matters were organised within the company. Because we were interested in institutionalisation, the nature of fields and institutional pressures, we sought views about connections to groups and individuals that may signal the existence of a field. The interview questions were 
derived from the sustainability, sustainability reporting, and institutional theory literature. We interview went.

The interviews were taped, with permission, and transcribed. The first stage of our analysis involved each of us independently reading through the transcripts, in their entirety, to get a feel for whether field-type differences stood out, and if there was a strong reaction to institutional pressure. We gained a clear impression of differences in interactions that our sample firms had with others. Taking heed of Hoffman (1999) and DiMaggio and Powell (1983) about the importance of interactions to field formation, we undertook a close and detailed reading to map the specific interactions that characterised our sample firms. As we explain below, we first looked to see if the differences cohered around industry, size and geography. Guided by Archel, Husillos, and Spence's (2011) study of how CSR has been institutionalised in Spain, we then examined the transcripts for evidence of isomorphism in discursive and material practices associated with the interaction patterns we observed. In an attempt to uncover the way varying discourses, or understandings of sustainability, were playing out we used NVIVO software to code statements that reflected 'weak', 'strong' or 'middle-ground' discourses of sustainability (see Bebbington, 2001; Laine, 2005; Milne, Tregidga, \& Walton, 2009 and further discussion of these discourses below). We undertook a similar coding exercise to capture the different types of practices and activities undertaken by each firm.

We ultimately found quite different patterns of isomorphism amongst those firms that interacted widely outside their industry compared to those that did not.

The second part of our analysis involved utilising Scott's (1995) specification of 'regulatory', 'normative' and 'cognitive' pressure to explore the nature of institutional pressure on reporting. Our intention was to develop a thorough insight in to the field(s) in which sustainability reporting was 'present', exactly how discourses shaped it in light of interaction patterns, and the institutional influences on how managers responded to it. 


\section{Results and Analysis}

This section is divided into two parts. Firstly, we describe the interaction patterns we observed that signal the existence of different salient institutional fields that influence how our managers understand sustainability, and their awareness and framing of the need for sustainability reporting. Following this, we explore the institutional pressures observable within each to highlight how institutional pressure shapes the reporting decisions in the fields we identify.

Table Two provides a snapshot of each company's interaction patterns.

Insert Table Two

Some patterns are observable:

- Almost all of the mining companies have contained interaction patterns confined to their industry and local geography

- Those companies with extensive interactions that span industries to include sustainability interest groups and other non-competing peer organisations, are larger (within the ASX100)

- Those companies with few inter-industry interactions are located in Western Australia and are smaller (within the ASX100-ASX200 band)

There are, however, exceptions:

- There is a smaller, WA-based mining company (M3) with extensive interactions with sustainability interest groups. The energy company (E3) is similar.

- Two of the other more contained companies are a retailer (R2) and a logistics firm (L1). While the logistics firm is located in Western Australia, the retailer is NSW-based. 
- Some mining companies with fewer interactions are large and two of them (M8 and M10) are ASX100 companies.

Caution thus needs to be exercised in asserting a geographical, West Australian, field in which sustainability reporting is absent, and also a size-based field, in which the smaller companies do not experience any pressure to report.

Our interest lies in how interaction patterns shape influences on sustainability reporting, so we explored the implications of the interactions, or lack of, between our sample firms and other noncompeting peer organisations, sustainability groups, and also consultants. We studied whether there was any isomorphism amongst those with extensive, inter-industry interaction patterns, and those that were more limited in the interactions they have.

\section{Organisational interactions and field formations}

\section{$\underline{\text { Industry-based Interactions and Contained Industry-Type Field(s) }}$}

Eleven of the 23 companies we studied have very limited interactions with sustainability related groups, and other non-competing peer organisations. Nine of these are mining companies, and the other two are a retailer and a logistics firm. In total nearly half our 23 sample companies have no interactions with sustainability-related organisations. In these firms, interactions are limited to industry connections, with some even having limited interactions with local business groups and their peers. One mining company revealed that, while they were a member of various industry groups, they did not engage widely:

It's like conferences, you see the same people presenting. And for us we don't do a lot of presentations, we don't go to a lot of conferences. We're very low key. 
We just believe we've got a job to do and that's [product], we're a [product]

(M8).

Within industry networks that predominated, there was little discussion of sustainability. For the miners, the most common industry body was the Association of Mining and Exploration Companies (AMEC). This organisation makes almost no mention of sustainability on its website and its recent conference focused on lowering regulation and reshaping the Government's indigenous agenda. Lobbying activities centre on repealing the Carbon Tax and the Minerals Resources Rent Tax (MRRT) (AMEC, 2013) [see note three]. Of the companies that did have connections to AMEC, the benefits were perceived as being limited, with several revealing there was no mention of sustainability within this body. The retailer and the logistics firm commented similarly about their interactions with their respective industry associations. The manager of the logistics firm revealed he was unaware of how the company's peers in the industry addressed sustainability.

The relatively tightly contained nature of the industry was compounded by intra-industry movement, particularly between the mining companies $[\mathrm{M} 1, \mathrm{M} 5, \mathrm{M} 8, \mathrm{M} 10]$ and the regulators:

I have been in the industry my whole life. Initially in government and in a regulatory role, first of in the water side, I was involved in some research and then went to the Environmental Protection Authority or the Department of Environment Protection it was then; it re-badges every couple of years. So I was on the other side of assessing these types of projects and ensuring compliance with the approval conditions, then went to Mineral Sands for seven years and then I was attracted to another iron ore group (M1).

Discussion of sustainability, when probed, was framed according to a 'weak' discourse that reflects a technocentric view of sustainability (Gladwin, Kennelly, \& Krause, 1995; Olsen, Lodwick, \& Dunlap, 1992). This discourse stands in contrast to 'strong' sustainability and is also different to a 'middle 
ground' discourse that permeates many business organisations (Higgins \& Walker, 2012). As shown in Table Three, these companies used few discursive references to strategy, stewardship, commitments, values, responsibility, emphasising instead efficiency, compliance, risk and instrumentality.

Insert Table Three

Illustrative of this discourse, is how this mining manager articulated their most pressing sustainability challenges:

\author{
The key issues for us are subterranean fauna, so troglodytic fauna; essentially \\ each of these now isolated palaeo channels hosts a different assemblage of \\ troglofauna that have been isolated genetically from the next palaeo channel and \\ the next one.... We looked at the remnants of those and they still have populations \\ of troglofauna of a similar type genius so you can infer that there is enough \\ volume there for a self-sustaining population (M1).
}

In contrast to values, responsibility and commitments, 'compliance' and 'cost' were emphasised, and were seen as desirable to minimise. One mining manager summed it up thus: "Yeah, we live in a nanny state and you know there's more and more and more compliance that's coming on-board" (M5). Typically, the pressures on the company and their obligations coalesced around economic impacts, with responsibility for environmental issues lying with government, or some NGOs. One mining company manager suggested that:

\footnotetext{
If we were doing the wrong thing I would hope some NGO was brave enough or interested enough to get up and say, 'This isn't good enough.' In Australia it's such a regulated environment; you know you don't get away with what a lot of less developing countries do (M4).
} 
Yeah [the environment manager] is on site so he does a lot of the reporting to the Department. But I don't know a lot about that; he takes care of that along with the operations director and the general manager up on site as well so that really is done from site.... (M8).

Similarly, operational managers had little awareness of how the company was run. For example, on being questioned about whether senior executives ever consider going beyond compliance, one replied "not that's directed to me" (R2). The operational managers we spoke to had no involvement in what was included in the annual report. Often, sustainability, and/or environment, were 'outsourced' to consultants to complete the compliance process.

There was little awareness of pro-active sustainability initiatives, including sustainability strategies, sustainability committees, standards, policies and benchmarking, amongst this group of firms. Publicly releasing compliance reports was seen as: “overkill, it's really an internal matter; it's not something that you really... I don't think that you would share with the general public" (M5). When asked about the general view of sustainability within the organisation, and whether any discussion occurred, a mining manager replied "Not a great deal" (M2) as did the retailer (R2). 
There was basically no discussion at all relating to sustainability reporting within these firms, and we had difficulty articulating exactly what it involved to the majority of these managers we interviewed. The managers were unfamiliar with reporting-related initiatives, for example, the GRI, and were seldom contacted by sustainability consultants. Asked about the GRI, one manager replied: "no...never heard of it...but you can be sure I'm now going to Google it" (M2). We also asked about the Government's mandatory National Greenhouse and Energy Reporting Scheme (NGERS - see note four) to which one replied "I'm not sure about that. I don't know, I'm not familiar with it" (M8). Questions relating to the Carbon Disclosure Project were met with similar responses (M1, M8, M10).

The few who were aware of sustainability reporting, had never viewed a sustainability report: "I can't say I've seen too many" (M8) and were baffled about why their peers reported. Few had considered expanding the information provided in the annual report. Overall, there was a degree of immaturity about reporting and disclosure. In response to our questions about a mention of CSR in one mining company's annual report, the manager replied: "Yeah, that was the motherhood statement. That was a compliance..." (M5).

For these firms with limited extra-industry interactions, the discourse and practices of sustainability are shaped by norms and pressures that predominate within the industry. These emphasise Government regulation that requires base-line assessments of flora and fauna, engagement with indigenous groups, detailed mine rehabilitation plans, and regular consultation with communities. Programs are required to manage impacts, and need to be submitted to a Government agency for approval. According to the mining managers, the extent of regulation leaves little 'room' for other sustainability activities; they were left pondering what else they would include in a voluntary sustainability report.

\section{Wide Inter-Industry Interactions and an Issues-Type Field}


In contrast, twelve (12) of the non-reporting firms, including two mining companies, had extensive

Our main competitors are in China and they do it very unsafely and very environmentally irresponsibly. So there's a good business reason for us to make sure that we produce these rare earths in a safe and environmentally responsible way and that is if you think about the Toyotas of the world who are making all these hybrid cars, at some point in time, they'll need to be exploring their supply chain and someone can ask them the question 'where are you getting your rare earths from?' and if they say China; and then you compare China's rare earth industry with us, we're going to be a lot cleaner and greener (M6).

We also found evidence that the interactions between these organisations led to a mutual exchange of ideas that also influenced company practice. A retailer suggested their involvement with others enables them to understand the global context, and keep a watching brief on developments, 
particularly Integrated Reporting in South Africa. The consumer staples firm describes how engagement with interest groups enables feedback and exposure:

Packaging covenant, yep, yep. We were an early adopter of the Sustainable Packaging Guidelines. So in our sustainability strategy, that fits under our products. ... We put all of our action plans through Australian Packaging Covenant and Responsible Round Table on Sustainable Palm Oil. Also our CDP report's publicly available; it's all there $(\mathrm{C} 1)$.

Most noticeably, the companies with extensive interactions shared a 'middle ground' discourse of sustainability (Colby, 1991; Livesey, 2002; Milne et al., 2009). This discourse reflects ecological modernisation, in which sustainability is important and is accommodated through gradual modification of existing systems (Rossi, Brown, \& Bass, 2000). As illustrated in Table Four, the emphasis on 'stakeholders', 'engagement', 'commitments', 'integration', and 'leadership' is shared by many of our interviewees (Tregidga \& Milne, 2006).

\section{Insert Table Four}

Stakeholder engagement, an external facing practice, has important influences on internal cultural change and learning, and assists the company to maintain a leadership position:

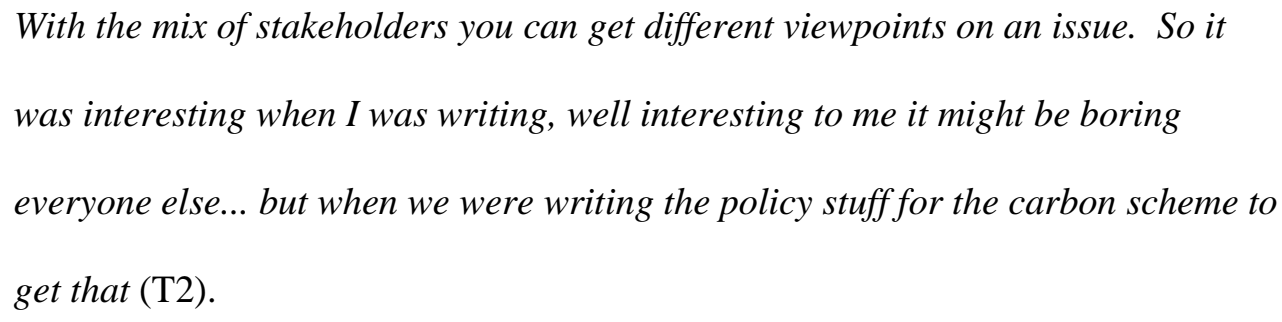

Thus, in contrast to the other set of companies we identified, these firms had close connections between external, corporate, and internal issues: 


\begin{abstract}
What we need to do is engage the organisation and create systemic change. So one of the first things that we did after the creation of our environment sustainability unit was to go to the executive and ask for their endorsement to create an environment working group and each executive has a representative that sits on that. We meet monthly (FS2).
\end{abstract}

\begin{abstract}
A 'middle ground' discourse of sustainability legitimises a range of voluntary, corporate-level sustainability-related practices that emphasise 'action', particularly: social, environmental and sustainability audits; senior management responsibility for sustainability; sustainability strategies; sustainability indicators; and Environmental Management Systems and certification (Iraldo, Testa, \& Frey, 2009). We found evidence of almost all of these practices across the firms we studied (see table four above). Surprisingly absent, however, was the practice of sustainability reporting. Studies of reporting in Spain, the UK and New Zealand show that sustainability reporting is common to this discourse (Archel et al., 2011; Livesey \& Kearins, 2002; Collins, Lawrence, Pavlovich, \& Ryan, 2007; Milne et al., 2009; O'Dwyer, 2002). Indeed sustainability reporting is seen as a key social practice in how this discourse is produced, reproduced and maintained.
\end{abstract}

We found that some firms did see sustainability reporting as inevitable (M3), and they were all aware of the GRI, indicating that while they did not report, they were aware of it. Their decision not to report was based on aspects of organisational culture, structural issues inside the company, and overlap with other types of reporting. The financial services firm argued that "you can't necessarily draw a line between the fact that because companies aren't doing a song and dance down Pitt Street, that there's nothing on inside the organisation" (FS1), while the transport company suggested that “we've got three very strong business divisions and we have a very low corporate focus. So we're not one of those companies where corporate says 'do this' and everyone does it...." (T2). The other transport company (T1) put their non-reporting down to a lack of resources. 
Others suggested they experienced no demand for more information, and a feeling that shareholders

Personal opinion, what is a sustainability report other than a PR brochure?

Would it not be better to spend your $\$ 100 \mathrm{~K}$, $\$ 200 \mathrm{~K}$ of production money on actual

efficiency projects? I'm all for open transparency, which is why we report

through CDP, the Dow Jones Sustainability Index and CDP Water for the first

time this year. So our information is out there in the public domain but we don't go to the trouble and expense of putting it in a fancy brochure.... (C1).

Thus there was a feeling that sustainability reporting does not deliver outcomes, and those that did it did so to support their differentiation and branding strategies:

I mean I think there are companies that really put their stamp on it and utilise it as a differentiation tool from their other competitors. But they, I think, have a really long term embedded approach to sustainability. I mean they have, from what I see and read in CSR Reports from various companies, they have embedded sustainability KPI's into scorecards and a bottom up approach rather than a sort of top down approach and it's a lot greater emphasis on those areas (G1).

Given the interaction patterns of these firms, and the similarities in how each discusses sustainability and attempts to operationalise it, it seems clear that a field has formed around the broader issue of 'business and sustainability'. This issues-type field extends beyond individual industries, and spans organisations of different sizes. Regardless of industry, size and geography there exist common understandings about stakeholder groups and their needs and expectations, and a set of common practices about making a contribution to sustainable development. 


\title{
Institutional Pressures
}

For those firms confined to industry-based interactions, there is no institutional pressure at all. Sustainability reporting is not any part of the field which dominates their rationality.

For the others, however, with extensive interactions and part of a sustainability-based issues field, sustainability reporting is 'normal', but not required or expected. The gambling firm summed up the general sentiment:

\author{
I think it's evolving and there's some pressure points coming into play, but I don't \\ think people view it as, it's not a mandatory thing, if you don't do it then you can \\ explain why you don't do it or you can put in more generalist statements... So I \\ think there's some traction in that space, but I don't think it's going to be \\ mandated...But I think the sort of the key areas that there are pressure on and \\ being mandated, like diversity and other sort of environmental stuff becoming \\ more prominent...(G1).
}

While regulatory pressure for some sustainability issues is present, it is not for sustainability reporting. Respondents identified the carbon tax, and the requirements for NGERS, and suggested regulation would be required before they produce a sustainability report: "Companies will only do what they're told to by the government... the government's energy efficiency opportunity scheme and the NGER reporting on greenhouse gases has driven lots of change” (T2). This type of regulation was, however, seen as unlikely. The feeling was that the Government is more focused on specific environmental outcomes (T2). 
Regulatory-type pressure was possible from other stakeholders who could impose sanctions, particularly rating agencies and indexes. There was, however, some doubt about the strength of the pressure that was exerted:

\author{
Look there are a couple of organisations out there that are asking listed \\ companies, and we've been asked as well, and politely declined, to provide or to \\ have more environmental reporting in your financial report and have auditors \\ conduct an audit of that environmental data etc. We responded by 'that's not our \\ priority, our priority is responsible gambling and it's not required by auditors to \\ do that sort of work' and so forth (G1).
}

\begin{abstract}
Normative-type pressure was similarly present, but nascent, limited in scope, and not directed at sustainability reporting. There was a felt need to respond to shareholders if expectations for increased disclosure did arise, reflecting a mix of their regulatory and normative rights to information. The consumer staples manager was adamant that: "If they ask for it, we'd provide it. We answer to them so we'd have to" (C1). Another pointed out that: "If one of our direct investors is saying this isn't good enough, we want you to report in the Carbon Disclosure Project or we want you to step up in this area, then that's when we respond" (T1). Few received pressure for information, however, revealing that like the regulators, investors are more interested in actual performance:
\end{abstract}

\author{
Shareholders don't really ask about it. We tell them what we're doing on the \\ environment, tell them we want to be, you know reduce our footprint and lowest \\ possible environmental impact; they get that, they like that, that's fine, that gives \\ them a sense of comfort that we don't ignore it (FS1).
}

Some cognitive-type pressure is apparent, particularly in the form of peer-pressure within the field. Some watch their competitors closely, and one revealed that pressure was coming through the 
networks of their senior managers. One mining company suggested there was peer-pressure amongst Australia's largest companies:

\begin{abstract}
Another reason I think just being a publicly listed company in Australia, in the top ASX100, that there's some peer pressure there in terms of what other good mining companies do (M3).
\end{abstract}

There is a feeling pressure to report will increase. A Financial Services executive opined that "I think it's here to stay...the trend is towards greater disclosure.... but I think it's going through one of those periods where it's again a constantly evolving area" (FS2). The transport executive suggested: "I am expecting the pressure to continue and potentially to increase, yes. So yeah, we'll see where that goes but we're bearing in mind that we might need at some point to step up...” (T1). The feeling was that the evolution was gradual: “I don't think there's any, there's no revolutionary sort of step going to happen in the near future, I can't see that happening" (G1). Another transport operator expected it to "just become a normal part of business and expectation...like safety" (T2). One felt that they had detected an increasing sophistication in the questions being asked, and the information being sought:

\author{
In the time that I've been here, the number of questions that are arising around \\ what organisations like ourselves are doing around ESG in particular, is \\ becoming more prevalent in those processes and the sophistication of the \\ questions is becoming more granular.... (FS1).
}

\title{
Discussion
}

Our study of non-reporting firms in fields where the institutionalisation of sustainability reporting is thought to be occurring reveals that it is not spreading to multiple fields. Instead, sustainability reporting is confined to a field built around a 'middle ground' discourse of sustainability more generally. Based on DiMaggio \& Powell's (1983) assertions that fields should be identified by a 
careful analysis of interaction patterns, we see clear patterns of discursive and material isomorphism attributed to the extent to which firms engage with sustainability interest groups, rating agencies, professional associations and business-related not-for-profit organisations.

The sustainability-related issues field we identify attracts diverse firms, but not all firms. Mostly, it would seem to attract those companies that share a commitment to sustainability, improving their social and environmental performance, and recognise the importance or necessity of doing so. Within this field, there is pressure for 'action' and 'responsiveness', and a number of normal and acceptable practices make up the appropriate response. These include appointing a sustainability manager, forming a sustainability committee, and engaging with stakeholders. Sustainability reporting is part of this suite of 'normal' practices, but there is little institutional pressure for this specific practice.

Several of the non-reporting firms we studied, however, have completely different and much more limited interaction patterns. They have almost no interactions with sustainability interest groups, sustainability-oriented business associations, rating agencies and other inter-industry groups. This suggests they clearly sit outside the issues-based sustainability field that influences the others we studied. What prevails for these firms are strong industry-related norms where issues such as sustainability are filtered through prevailing industry-based logic. It is not that sustainability reporting and other sustainability-related practices are avoided; they are not even present as part of the fields that shape sustainability-related thinking. These firms do not avoid or resist institutional pressure to report, they do not experience it.

The interaction patterns and the associated patterns of behaviour we observed suggest that the 'progressive' middle ground discourse of sustainability is not 'spreading'. Based on the patterns we observed, it is difficult to see how it would penetrate strong industry-dominated fields. The economic and techno-scientific rationality is constantly reproduced through the insular interactions and tight recruitment practices within the field. New insights about sustainability are not emerging within this field, and would most likely need to come from an external shock or jolt, or an 'insider' having an 
epiphany that encourages them to take a leadership role and bring about change (Garud, Hardy, \& Maguire, 2007). These individuals will, however, face a tough job because where pressure has been felt for a more 'progressive' sustainability stance from, for example, investors or rating agencies, the dominant rationality towards economics and regulation casts the pressures as unrealistic, fringe or unnecessary. The complete lack of a middle-ground discourse also renders other practices such as sustainability committees, sustainability managers, engagement, strategy and culture invisible and illegitimate.

Within the firms with limited interactions, the large cluster of mining companies is interesting, especially given observations within the literature that the mining companies have been amongst the earliest and most prolific of the sustainability reporters (Raufflet, Barin Cruz, \& Bres, 2014; Vintró, Sanmiquel, \& Freijo, 2014). Given the number of relatively large mining companies we found in our sample, it does not seem as if they are outliers. Consistent with our argument it would seem that those that $d o$ report and $d o$ express the somewhat progressive 'middle ground' discourse of sustainability, could well be part of the sustainability-related issues field discussed above.

\section{Conclusion}

The issue at the heart of this study is that a number of firms assumed to be likely to report based on their strategic or organisational characteristics do not, and an increasing number of firms that would seem unlikely to benefit from reporting do report (Higgins et al., 2015). Institutional studies have drawn attention to the pressures that arise in size, geographical and industry-based fields to explain these patterns, but this work is under developed. Our aim was to extend the growing institutional work by studying the interaction patterns that non-reporting companies have, in an attempt to develop a clearer picture of the salient field(s) for sustainability reporting activity.

Our analysis reveals that the institutional dynamic associated with sustainability reporting is not necessarily size, industry or geographical based, but issues-based. For those that need to, or desire to, be associated with sustainability the interaction they seek out and initiate leads to isomorphism in 
discursive and material practice around sustainability. Sustainability is something that has come to

Additionally, further attention can now be given to what encourages some firms to report once they become part of a new field, and why some companies within fields do not report. Clearly, the structuring of the middle-ground discourse plays a role, as does the nature and type of institutional pressure that exists within the field, but this does not account for individual differences between firms within fields. This too may be influenced by organisational characteristics or strategic motivations (as per Solomon \& Lewis, 2002)(as per Solomon \& Lewis, 2002)(as per Solomon \& Lewis, 2002)(as per Solomon \& Lewis, 2002)(as per Solomon \& Lewis, 2002) that explain some reporting activities (as per Adams, 2002). 
For those interested in encouraging more companies to undertake sustainability reporting, further attention needs to be given to how other field members, for example, NGOs and sustainability interest groups, can be supported to exert the types of pressures that will bring about reporting activity. In particular, what types of sanctions will support the regulatory pressure of the rating agencies? How can normative pressure that rests on some social consensus about what is right be strengthened? Is there room for regulation of disclosure, in which case what form should this take, and what should be required?

The contribution of our study is that institutional theory offers a valuable lens for understanding sustainability reporting. We also show that inter-institutional dynamics are complex and there are clearly different types of fields with the interactions between them requiring some consideration. New directions in institutional theory that focus on institutional complexity, the hierarchy, relationship, and contest between multiple institutional fields and agency on the part of managers to shape, avoid or resist institutional pressure could be incorporated in to subsequent studies of institutionalisation of sustainability reporting (Zietsma \& Lawrence, 2010; Dillard, Rigsby, \& Goodman, 2004; Seo \& Creed, 2002; Garud et al., 2007). 
1. In Australa, as elsewhere, there is some ambiguity concerning the terminology used by business organisations when describing their reporting efforts, with 'Sustainability Reporting, 'Social/Environmental Reporting' and sometimes 'triple bottom line reporting' all being used. We use the term 'sustainability reporting' to capture the general category of reports that companies voluntarily produce to disclose social and environmental performance data, impacts, policies and targets.We also use this term to describe previous voluntary reporting attempts, including social reporting and environmental reporting.

2. The Global Reporting Initiative suggests that sustainability reports disclose outcomes and results that occur within a reporting period in the context of the organisation's commitments, strategy, and management approach. It includes a profile of the reporting organisation, a description of the management approach taken to manage social/environmental issues, and a series of relevant performance indicators.

3. The Carbon Tax was introduced by Australia's Federal Labor government in 2012. It set a price on carbon emissions, with the view to gradually evolving to a market-based system. The Minerals Resources Rent Tax (MRRT), or 'Mining Tax', was introduced by the Federal Government in 2011 after much debate and industry lobbying. It was designed to redistribute the 'super profits' being made by the most profitable mining companies to other areas of Australian society. Both were repealed in early 2014 by the new conservative government.

4. The Australian Government requires companies to report under the National Greenhouse and Energy Reporting Scheme (NGERS) if they have operational control of a facility that emits equal to or greater than 25000 tonnes of $\mathrm{CO} 2 \mathrm{e}(\mathrm{tCO} 2 \mathrm{e})$ and/or produces equal to or greater than 100 terajoules (TJ) of energy and/or consumes equal to or greater than $100 \mathrm{TJ}$ of energy. Reporting is also required if the corporate group emits equal to or greater than $125000 \mathrm{tCO} 2 \mathrm{e}$ and/or produces equal to or greater than $500 \mathrm{TJ}$ of energy and/or consumes equal to or greater than $500 \mathrm{TJ}$ of energy. See http://www.climatechange.gov.au/climate-change/greenhouse-gas-measurement-andreporting/company-emissions-measurement/national. In addition to this, companies that use more than 0.5 petajoules $(\mathrm{PJ})$ of energy per year are required to participate in the Government's Energy Efficiency Opportunities program that requires them to identify, evaluate and report publicly on cost effective energy savings opportunities. There are more than 220 corporations, incorporating around 1200 subsidiaries, registered for the Energy Efficiency Opportunities program. See http://www.ret.gov.au/energy/efficiency/eeo/Pages/default.aspx

5. These include Net Balance (see http://www.netbalance.com.au) and The Australian Centre for Corporate Social Responsibility (ACCSR - see http://www.accsr.com.au) which are Australian consultancies that offer services, training and research into various social responsibility and sustainability issues (including sustainability reporting) for (mostly) corporate organisations. 


\section{References}

Adams, C. 2002. Internal organisational factors influencing social and ethical reporting: Beyond current theorising. Accounting, Auditing and Accountability, 15(2): 223-250.

Aerts, W., Cormier, D., \& Magnan, M. 2006. Intra-industry imitation in corporate environmental reporting: An international perspective. Journal of Accounting and Public Policy, 25(3): 299-331.

Andersen, O. 2003. Environmental reporting and transport - the case of a public transport company. Business Strategy \& the Environment (John Wiley \& Sons, Inc), 12(6): 386-399.

Archel, P., Fernández, M., \& Larrinaga, C. 2008. The organizational and operational boundaries of triple bottom line reporting: A survey. Environmental Management, 4: 106-117.

Archel, P., Husillos, J., \& Spence, C. 2011. The institutionalisation of unaccountability: Loading the dice of corporate social responsibility discourse. Accounting, Organizations and Society, 36: 327-343.

Australian Council of Superannuation Investors. 2011. Sustainability reporting practices of the S\&P/ASX200. Melbourne, Australia: Author.

Bansal, P., \& Roth, K. 2000. Why companies go green: A model of ecological responsiveness. Academy of Management Journal, 43(4): 717-736.

Barkemeyer, R., Preuss, L., \& Lee, L. 2015. On the effectiveness of private transnational governance regimesEvaluating corporate sustainability reporting according to the Global Reporting Initiative. Journal of World Business, 50(2): 312-325.

Barreto, I., \& Baden-Fuller, C. 2006. To conform or to perform? Mimetic behaviour, legitimacy-based groups and performance consequences. Journal of Management Studies, 43(7): 1559-1581.

Bebbington, J. 1997. Engagement, education and sustainability: A review essay on environmental accounting. Accounting, Auditing and Accountability Journal, 10(3): 365-381.

Bebbington, J. 2001. Sustainable development: A review of the international development, business and accounting literature. Accounting Forum, 25(2): 128-157.

Bebbington, J., Higgins, C., \& Frame, B. 2009. Initiating sustainable development reporting: Evidence from New Zealand. Accounting, Auditing and Accountability Journal, 22(4): 588-625.

Boxenbaum, E. 2006. Corporate social responsibility as institutional hybrids. Journal of Business Strategies, 23(1): 1-31.

Chen, S., \& Bouvain, P. 2009. Is Corporate Responsibility Converging? A Comparison of Corporate Responsibility Reporting in the USA, UK, Australia, and Germany. Journal of Business Ethics, 87(ArticleType: research-article / Issue Title: Supplement 1: Globalization and the Good Corporation / Full publication date: 2009 / Copyright $\odot 2009$ Springer): 299-317.

Choudhury, N. 1988. The seeking of accounting where it is not: Towards a theory of non-accounting in organizational settings. Accounting, Organizations and Society, 13(6): 549-557.

de Villiers, C., \& Alexander, D. 2014. The institutionalisation of corporate social responsibility reporting British Accounting Review, 46(2): 198-212.

de Villiers, C., Low, M., \& Samkin, G. 2014. The institutionalisation of mining company sustainability disclosures. Journal of Cleaner Production, 84: 51-58.

Deegan, C. 2002. The legitimising effect of social and environmental disclosures: A theoretical foundation. Accounting, Auditing and Accountability Journal, 15(3): 282-311.

Deegan, C., Rankin, M., \& Tobin, J. 2002. An examination of the corporate social and environmental disclosures of BHP from 1983-1997: A test of legitimacy theory. Accounting, Auditing and Accountability Journal, 15(3): 312-343.

Deegan, C., Rankin, M., \& Voght, P. 2000. Firms' Disclosure Reactions to Major Social Incidents: Australian Evidence. Accounting Forum, 24(1): 101-130.

del Mar Alonso-Almeida, M., Llach, J., \& Marimon, F. 2014. A Closer Look at the 'Global Reporting Initiative' Sustainability Reporting as a Tool to Implement Environmental and Social Policies: A Worldwide Sector Analysis. Corporate Social Responsibility and Environmental Management, 21(6): 318-335.

DiMaggio, P. 1991. Constructing an organizational field as a professional project: US art museums, 1920-1940. In W. Powell, \& P. DiMaggio (Eds.), The new institutionalism in organizational analysis: 267-292. Chicago: University of Chicago Press. 
DiMaggio, P., \& Powell, W. 1983. The iron cage revisited: Institutional isomorphism and collective rationality in organizational fields. American sociological review, 48: 147-160.

DiMaggio, P., \& Powell, W. 1991. Introduction. In P. Powell, \& W. DiMaggio (Eds.), The new institutionalism in organizational analysis: 1-38. Chicago and London: The University of Chicago Press.

Douglas, T. 2007. Reporting on the triple bottom line at Cascade Engineering. Global Business \& Organizational Excellence, 26(3): 35-43.

Fifka, M. 2011. Corporate responsibility reporting and its determinants in comparative perspective: A review of the empirical literature and a meta-analysis. Business, Strategy \& the Environment.

Friedland, R., \& Alford, R. 1991. Bringing society back in: Symbols, practices, and institutional contradictions. In W. Powell, \& P. DiMaggio (Eds.), The new institutionalism in organizational analysis: 232-263. Chicago: University of Chicago Press.

Galaskiewicz, J. 1991. Making corporate actors accountable: Institution building in Minneapolis-St. Paul. In W. Powell, \& P. DiMaggio (Eds.), The new institutionalism in organizational studies: 293-310. Chicago: University of Chicago Press.

Garud, R., Hardy, C., \& Maguire, S. 2007. Institutional entrepreneurship as embedded agency: An introduction to the special issue. Organization Studies, 28(7): 957-969.

Gladwin, T., Kennelly, J., \& Krause, T. 1995. Shifting paradigms for sustainable development: Implications for theory and research. Academy of Management Review, 20(4): 874-907.

Golob, U., \& Bartlett, J. 2007. Communicating about corporate social responsibility: A comparative study of CSR reporting in Australia and Slovenia. Public Relations Review, 33(1): 1-9.

Gray, R., \& Bebbington, J. 2007. Corporate sustainability, accountability and the pursuit of the impossible dream. In G. Atkinson, S. Dietz, \& E. Numeyer (Eds.), Handbook of sustainable development. Cheltenham, UK: Edward Elgar.

Gürtürk, A., \& Hahn, R. Forthcoming. An empirical assessment of assurance statements in sustainability reports: Smoke screens or enlightening information? . Journal of Cleaner Production.

Hardy, C., \& Maguire, S. 2010. Discourse, field-configuring events, and change in organizations and institutional fields: Narratives of DDT and the Stockholm convention. Academy of Management Journal, 53(6): 1365-1392.

Herremans, I. M., Herschovis, S. M., \& Bertels, S. 2008. Leaders and laggards: The influence of competing logics on corporate environmental action. Journal of Business Ethics, 89(7): 449-472.

Higgins, C., \& Larrinaga, C. 2014. Sustainability reporting: Insights from institutional theory. In J. Unerman, J. Bebbington, \& B. O'Dwyer (Eds.), Sustainability Accounting and Accountability, 2nd ed. London: Routledge.

Higgins, C., Milne, M., \& van Gramberg, B. 2015. The uptake of sustainability reporting in Australia. Journal of Business Ethics, 129(2): 445-468.

Higgins, C., \& Walker, R. 2012. Ethos, logos, pathos: Strategies of persuasion in social/environmental reports. Accounting Forum, 36(3): 194-208.

Hoffman, A. 1999. Institutional evolution and change: Environmentalism and the US chemical industry. Academy of Management Journal, 42(4): 351-371.

Hoffman, A. 2001. Linking organizational and field-level analyses: The diffusion of corporate environmental practice. Organization \& Environment, 14(2): 133-156.

Hoffman, A., \& Ocasio, W. 2001. Not all events are attended equally: Toward a middle-range theory of industry attention to external events. Organization Science, 12(4): 414-434.

Iraldo, F., Testa, F., \& Frey, M. 2009. Is an environmental management system able to influence environmental and competitive performance? The case of the eco-management and audit scheme (EMAS) in the European union. Journal of Cleaner Production, 17(16): 1444-1452.

Kolk, A. 2003. Trends in sustainability reporting by the Fortune Global 250. Business strategy and the environment, 12(5): 279-291.

Kolk, A. 2005. Environmental reporting by multinationals from the triad: Convergence or divergence? Management International Review, 45(1): 145-166.

Kolk, A. 2007. On the economic dimensions of corporate social responsibility: Exploring fortune global 250 reports. Business and Society, 46(4): 457-478.

Kolk, A. 2008. Sustainability, accountability and corporate governance: Exploring multinationals' reporting practices. Business, Strategy \& the Environment, 17(1): 1-15. 
Kolk, A. 2010a. Social and sustainability dimensions of regionalization and (semi)globalization. The Multinational Business Review, 18(1): 51-72.

Kolk, A. 2010b. Trajectories of Sustainability Reporting by MNCs. Journal of World Business, 45(4): 367-374.

Kolk, A. 2011. Harmonization in CSR reporting MNEs and global CSR standards. Management International Review, 51(5).

Kolk, A., Walhain, S., \& van de Wateringen, S. 2001. Environmental reporting by the Fortune Global 250: exploring the influence of nationality and sector. Business Strategy \& the Environment (John Wiley \& Sons, Inc), 10(1): 15-28.

Kostova, T., \& Zaheer, S. 1999. Organizational legitimacy under conditions of complexity: The case of the multinational enterprise. Academy of Management Review, 24(1): 64-81.

KPMG. 2005. International survey of corporate social responsibility reporting 2005. Amsterdam: KPMG International.

KPMG. 2008. International survey of corporate social responsibility reporting, 2008. Amsterdam: KPMG International.

KPMG. 2011. The KPMG survey of corporate social responsibility reporting. London: KPMG.

Laine, M. 2005. Meanings of the term 'sustainable development' in Finnish corporate disclosures. Accounting Forum, 29(4): 395-413.

Larrinaga, C. 2007. Sustainability reporting: Insights from neo-institutional theory. In J. Unerman, J. Bebbington, \& B. O'Dwyer (Eds.), Sustainability accounting and accountability. London: Routledge.

Lawrence, T., Suddaby, R., \& Leca, B. 2011. Institutional work: Refocusing studies of organization. Journal of Management Inquiry, 20(1): 52-58.

Lindblom, C. K. 1993. The implications for organizational legitimacy for corporate social performance and disclosure. Proceedings of the Critical Perspectives on Accounting conference, New York.

Lounsbury, M., Ventresca, M., \& Hirsch, P. 2003. Social movements, field frames and industry emergence: A cultural-political perspective on US recycling. Socio-Economic Review, 1(2): 71-102.

Maguire, S., Hardy, C., \& Lawrence, T. 2004. Institutional entrepreneurship in emerging fields: HIVIAIDS treatment advocacy in Canada. Academy of Management Journal, 47(5): 657-679.

Meyer, J., \& Scott, R. 1992. Organizational environments: Ritual and rationality. Newbury Park, CA: Sage.

Milne, M., \& Gray, R. 2007. Future prospects for corporate sustainability reporting. In J. Unerman, J. Bebbington, \& B. O'Dwyer (Eds.), Sustainability Accounting and Accountability. London: Routledge.

Milne, M., \& Gray, R. 2013. W(h)ither ecology? The triple bottom line, the global reporting initiative, and corporate sustainability reporting. Journal of Business Ethics, 118(1): 13-29.

Milne, M., \& Patten, D., M. . 2002. Securing organizational legitimacy: An experimental decision case examining the impact of environmental disclosures. Accounting, Auditing \& Accountability Journal, 15(3): $372-$ 405.

Milne, M., Tregidga, H., \& Walton, S. 2009. Words not actions! The ideological role of sustainable development reporting. Accounting, Auditing and Accountability Journal, 22(8): 1211-1257.

Morhardt, J. 2010. Corporate social responsibility and sustainability reporting on the Internet. Business, Strategy \& the Environment, 19(7): 436-452.

O'Sullivan, N., \& O'Dwyer, B. 2015. The structuration of issue-based fields: Social accountability, social movements and the Equator Principles issue-based field. Accounting, Organizations and Society, 43(C): 33-55.

Oliver, C. 1991. Strategic responses to institutional pressure. Academy of Management Review, 16(1): 145179.

Olsen, M., Lodwick, D., \& Dunlap, R. 1992. Viewing the world ecologically. Boulder, CO: Westview Press.

Owen, D. 2008. Chronicles of wasted time?: A personal reflection on the current state of, and future prospects for, social and environmental accounting research. Accounting, Auditing \& Accountability Journal, 21(2): 240-267.

Phillips, N., Lawrence, T., \& Hardy, C. 2004. Discourse and institutions. Academy of Management Review, 29(4): 635-652.

Raufflet, E., Barin Cruz, L., \& Bres, L. 2014. An assessment of corporate social responsibility practices in the mining and oil and gas industries. Journal of Cleaner Production, 84(0): 256-270.

Rossi, G., Brown, H. S., \& Bass, L. 2000. Leaders in sustainable development: How agents of change define the agenda. Business Strategy \& the Environment, 9(5): 273-286.

Scott, R. 1995. Institutions and Organizations. Thousand Oaks: Sage. 
Solomon, A., \& Lewis, L. 2002. Incentives and disincentives for corporate environmental disclosure. Business Strategy \& the Environment, 11(2): 154-169.

Stubbs, W., Higgins, C., \& Milne, M. 2013. Why do companies not produce sustainability reports? Business, Strategy \& the Environment, 22(7): 456-470.

Tregidga, H., \& Milne, M. 2006. From sustainable management to sustainable development: A longitudinal analysis of a leading New Zealand environmental reporter. Business, Strategy and the Environment, 15(4): 219-241.

Vintró, C., Sanmiquel, L., \& Freijo, M. 2014. Environmental sustainability in the mining sector: evidence from Catalan companies. Journal of Cleaner Production, 84(0): 155-163.

White, H. 1992. Identity and control: a structural theory of social interaction. Princeton, NJ: Princeton University Press.

Young, S., \& Marais, M. 2012. A multi-level perspective of CSR Reporting: The implications of national institutions and industry risk characteristics. Corporate Governance: An International Review, 20(5): 432-450.

Zeitz, G., Mittal, V., \& McAuly, B. 1999. Distinguishing adoption and entrenchment of management practices: A framework analysis. Organization Studies, 20(5): 741-776. 
Sustainability reporting institutionalised?

Table One: Research Positions, Industry and Location

\begin{tabular}{|c|c|c|c|c|}
\hline Participant & Industry Sector & $\begin{array}{l}\text { ASX } \\
\text { Position }\end{array}$ & Location & Participant's position \\
\hline $\mathrm{C} 1$ & $\begin{array}{l}\text { Consumer } \\
\text { Staples/Retail }\end{array}$ & ASX200 & $\begin{array}{ll}\text { New } & \text { South } \\
\text { Wales } & \\
\end{array}$ & Sustainability Manager \\
\hline E1 & Energy & ASX100 & Victoria & $\begin{array}{l}\text { Investor Relations } \\
\text { Manager }\end{array}$ \\
\hline E2 & Energy & ASX100 & $\begin{array}{l}\text { New } \quad \text { South } \\
\text { Wales }\end{array}$ & $\begin{array}{l}\text { Corporate Sustainability } \\
\text { Officer }\end{array}$ \\
\hline E3 & Energy/Mining & ASX200 & West Australia & $\begin{array}{l}\text { General Manager, } \\
\text { Sustainable Development }\end{array}$ \\
\hline FS1 & Financial Services & ASX100 & $\begin{array}{ll}\text { New } & \text { South } \\
\text { Wales } & \end{array}$ & $\begin{array}{l}\text { Head of Environment, } \\
\text { Social \& Governance }\end{array}$ \\
\hline FS2 & Financial Services & ASX100 & Victoria & $\begin{array}{l}\text { Head of Environment \& } \\
\text { Sustainability }\end{array}$ \\
\hline G1 & Gaming/Gambling & ASX100 & Victoria & $\begin{array}{l}\text { Company Secretary } \\
\text { General Manager - Group } \\
\text { Corporate Affairs }\end{array}$ \\
\hline L1 & Logistics & ASX200 & West Australia & $\begin{array}{l}\text { General Manager - } \\
\text { Health, Safety, } \\
\text { Environment and Quality }\end{array}$ \\
\hline M1 & Mining & ASX200 & West Australia & $\begin{array}{l}\text { Manager, Environment \& } \\
\text { Community }\end{array}$ \\
\hline M2 & Mining & ASX200 & West Australia & $\begin{array}{l}\text { Principal Environment } \\
\text { Advisor } \\
\text { Senior Environment } \\
\text { Advisor }\end{array}$ \\
\hline M3 & Mining & ASX200 & West Australia & Environment Manager \\
\hline M4 & Mining & ASX200 & West Australia & Chairman \\
\hline M5 & Mining & ASX200 & West Australia & Company Secretary \\
\hline M6 & Mining & ASX200 & West Australia & $\begin{array}{l}\text { General Manager - } \\
\text { Safety, Health, } \\
\text { Environment and } \\
\text { Community }\end{array}$ \\
\hline M7 & Mining & ASX200 & West Australia & $\begin{array}{l}\text { Vice President - Business } \\
\text { Development }\end{array}$ \\
\hline M8 & Mining & ASX100 & West Australia & Company Secretary/CFO \\
\hline M9 & Mining & ASX200 & West Australia & $\begin{array}{l}\text { Manager - Environment } \\
\text { \& Community }\end{array}$ \\
\hline M10 & Mining & ASX100 & West Australia & $\begin{array}{l}\text { Group Environment } \\
\text { Manager }\end{array}$ \\
\hline R1 & Retail & ASX100 & $\begin{array}{ll}\text { New } & \text { South } \\
\text { Wales } & \end{array}$ & Environment Manager \\
\hline $\mathrm{R} 2$ & Retail & ASX200 & $\begin{array}{ll}\text { New } & \text { South } \\
\text { Wales } & \end{array}$ & Procurement Manager \\
\hline $\mathrm{R} 3$ & Retail & ASX200 & Victoria & Sustainability Manager \\
\hline $\mathrm{T} 1$ & Transport & ASX100 & West Australia & $\begin{array}{l}\text { Manager, Strategy \& } \\
\text { Marketing }\end{array}$ \\
\hline $\mathrm{T} 2$ & Transport & ASX100 & $\begin{array}{l}\text { New South } \\
\text { Wales }\end{array}$ & $\begin{array}{l}\text { National Manager - } \\
\text { Environmental } \\
\text { Sustainability Planning }\end{array}$ \\
\hline
\end{tabular}


Table Two: Interaction Patterns

\begin{tabular}{|c|c|c|c|c|c|c|c|c|c|}
\hline Interviewee & Industry & State & Size & $\begin{array}{l}\text { Sustainability- } \\
\text { related } \\
\text { business } \\
\text { group }\end{array}$ & $\begin{array}{l}\text { Other (non- } \\
\text { competing) } \\
\text { peer } \\
\text { organisations }\end{array}$ & Consultants & $\begin{array}{l}\text { Industry- } \\
\text { association }\end{array}$ & $\begin{array}{l}\text { Role-based } \\
\text { group or } \\
\text { association }\end{array}$ & $\begin{array}{l}\text { Local } \\
\text { geographical } \\
\text { based group or } \\
\text { association }\end{array}$ \\
\hline M3 & Mining & WA & ASX200 & $\sqrt{1}$ & & $\sqrt{ }$ & $\sqrt{ }$ & & $\sqrt{ }$ \\
\hline FS1 & $\begin{array}{l}\text { Financial } \\
\text { Services }\end{array}$ & NSW & ASX100 & $\sqrt{ }$ & $\sqrt{ }$ & $\sqrt{ }$ & $\sqrt{ }$ & & \\
\hline FS2 & $\begin{array}{l}\text { Financial } \\
\text { Services }\end{array}$ & VIC & ASX100 & $\sqrt{ }$ & & $\sqrt{ }$ & & & $\sqrt{ }$ \\
\hline R1 & Retail & NSW & ASX100 & $\sqrt{ }$ & $\sqrt{ }$ & $\sqrt{ }$ & $\sqrt{ }$ & $\sqrt{ }$ & \\
\hline $\mathrm{C} 1$ & $\begin{array}{l}\text { Consumer } \\
\text { Staples/Retail }\end{array}$ & NSW & ASX100 & $\sqrt{ }$ & $\sqrt{ }$ & $\sqrt{ }$ & $\sqrt{ }$ & $\sqrt{ }$ & $\sqrt{ }$ \\
\hline $\mathrm{T} 1$ & Transport & WA & ASX100 & $\sqrt{ }$ & & & $\sqrt{ }$ & & $\sqrt{ }$ \\
\hline $\mathrm{T} 2$ & Transport & NSW & ASX100 & $\sqrt{ }$ & $\sqrt{ }$ & $\sqrt{ }$ & $\sqrt{ }$ & & \\
\hline E1 & Energy & VIC & ASX100 & $\sqrt{ }$ & $\sqrt{ }$ & & $\sqrt{ }$ & & $\sqrt{ }$ \\
\hline G1 & Gambling & VIC & ASX100 & $\sqrt{ }$ & $\sqrt{ }$ & $\sqrt{ }$ & $\sqrt{ }$ & $\sqrt{ }$ & $\sqrt{ }$ \\
\hline E2 & Energy & NSW & ASX100 & $\sqrt{ }$ & $\sqrt{ }$ & $\sqrt{ }$ & $\sqrt{ }$ & & $\sqrt{ }$ \\
\hline E3 & Energy & WA & ASX200 & $\sqrt{ }$ & $\sqrt{ }$ & $\sqrt{ }$ & $\sqrt{ }$ & $\sqrt{ }$ & $\sqrt{ }$ \\
\hline R3 & Retail & VIC & ASX200 & $\sqrt{ }$ & $\sqrt{ }$ & $\sqrt{ }$ & $\sqrt{ }$ & $\sqrt{ }$ & \\
\hline M6 & Mining & WA & ASX200 & & & $\sqrt{ }$ & $\sqrt{ }$ & $\sqrt{ }$ & $\sqrt{ }$ \\
\hline M9 & Mining & WA & ASX200 & & & & $\sqrt{ }$ & & \\
\hline M1 & Mining & WA & ASX200 & & & & $\sqrt{ }$ & & $\sqrt{ }$ \\
\hline M2 & Mining & WA & ASX200 & & & $\sqrt{ }$ & $\sqrt{ }$ & & $\sqrt{ }$ \\
\hline M4 & Mining & WA & ASX200 & & & & $\sqrt{ }$ & $\sqrt{ }$ & \\
\hline M5 & Mining & WA & ASX200 & & & & $\sqrt{ }$ & & \\
\hline M7 & Mining & WA & ASX200 & & & & $\sqrt{ }$ & $\sqrt{ }$ & $\sqrt{ }$ \\
\hline M8 & Mining & WA & ASX100 & & & & $\sqrt{ }$ & $\sqrt{ }$ & $\sqrt{ }$ \\
\hline M10 & Mining & WA & ASX100 & & & & $\sqrt{ }$ & & $\sqrt{ }$ \\
\hline L1 & Logistics & WA & ASX200 & & $\sqrt{ }$ & $\sqrt{ }$ & $\sqrt{ }$ & & $\sqrt{ }$ \\
\hline R2 & Retail & NSW & ASX200 & & $\sqrt{ }$ & & $\sqrt{ }$ & & \\
\hline
\end{tabular}


Table Three: Discursive and Material Practices of those with confined interactions

\begin{tabular}{|c|c|c|c|c|c|c|c|c|c|c|c|c|}
\hline & M1 & M2 & M4 & M5 & M6 & M7 & M8 & M9 & M10 & L1 & $\mathrm{R} 2$ & $\mathrm{R} 1$ \\
\hline \multicolumn{13}{|l|}{ Discursive Practices } \\
\hline \multicolumn{13}{|l|}{ Win/Win, opportunities } \\
\hline $\begin{array}{l}\text { Strategy, competitiveness, marketing, } \\
\text { positioning, leadership }\end{array}$ & & & & & $\sqrt{ }$ & & & & & $\sqrt{ }$ & & \\
\hline Stewardship & & & $\sqrt{ }$ & & & & & $\sqrt{ }$ & & & $\sqrt{ }$ & \\
\hline \multicolumn{13}{|l|}{ Commitments, leadership } \\
\hline Credentials, walk-the-talk & & & & $\sqrt{ }$ & $\sqrt{ }$ & & & & & & $\sqrt{ }$ & \\
\hline Values, Values-led, responsibility & & & & & $\sqrt{ }$ & & & & & & & \\
\hline Trust, relationships & & & & & & & $\sqrt{ }$ & $\sqrt{ }$ & $\sqrt{ }$ & & & \\
\hline $\begin{array}{l}\text { Engagement, community, staff, } \\
\text { conversations, dialogue }\end{array}$ & & & $\sqrt{ }$ & & $\sqrt{ }$ & & & & & & & \\
\hline $\begin{array}{l}\text { Continuous improvement, } \\
\text { integration/embedding, best practice, } \\
\text { change }\end{array}$ & $\sqrt{ }$ & & & & & & & & & & & \\
\hline $\begin{array}{l}\text { Clean and Green, environmental } \\
\text { footprint, doing the right thing }\end{array}$ & & & & & $\sqrt{ }$ & & & & & & $\sqrt{ }$ & \\
\hline Materiality, business-case & & & & & & & $\sqrt{ }$ & & & & $\sqrt{ }$ & \\
\hline Rehabilitation, operations & $\sqrt{ }$ & $\sqrt{ }$ & $\sqrt{ }$ & $\sqrt{ }$ & $\sqrt{ }$ & $\sqrt{ }$ & $\sqrt{ }$ & $\sqrt{ }$ & $\sqrt{ }$ & & & \\
\hline Efficiency & $\sqrt{ }$ & $\sqrt{ }$ & & $\sqrt{ }$ & & & & $\sqrt{ }$ & $\sqrt{ }$ & & & \\
\hline Risk & & $\sqrt{ }$ & $\sqrt{ }$ & & $\sqrt{ }$ & & & & & $\sqrt{ }$ & & \\
\hline Techno-scientific & $\sqrt{ }$ & $\sqrt{ }$ & $\sqrt{ }$ & $\sqrt{ }$ & $\sqrt{ }$ & $\sqrt{ }$ & & $\sqrt{ }$ & & & & \\
\hline Instrumental & $\sqrt{ }$ & & & $\sqrt{ }$ & $\sqrt{ }$ & & $\sqrt{ }$ & $\sqrt{ }$ & $\sqrt{ }$ & & & \\
\hline Compliance & $\sqrt{ }$ & $\sqrt{ }$ & $\sqrt{ }$ & $\sqrt{ }$ & & $\sqrt{ }$ & $\sqrt{ }$ & & $\sqrt{ }$ & $\sqrt{ }$ & & \\
\hline Conservatism & & & & & & & $\sqrt{ }$ & & & & & \\
\hline \multicolumn{13}{|l|}{ 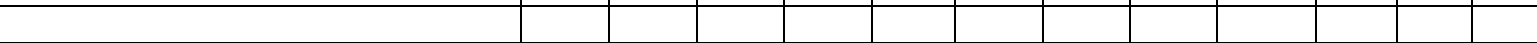 } \\
\hline Material Practices & & & & & $\sqrt{ }$ & & & & & & & \\
\hline \multicolumn{13}{|l|}{$\begin{array}{l}\text { Sustainability, social, environment } \\
\text { Strategy }\end{array}$} \\
\hline Board Committee & & & & & $\sqrt{ }$ & & & & & & & \\
\hline Environmental Management System & $\sqrt{ }$ & & & & $\sqrt{ }$ & & & & & $\sqrt{ }$ & & \\
\hline Certification (eg ISO26000, 14001) & & & & & $\sqrt{ }$ & & & & & $\sqrt{ }$ & & \\
\hline $\begin{array}{l}\text { Operating Standards, policies, } \\
\text { procedures, benchmarking }\end{array}$ & $\sqrt{ }$ & & & & $\sqrt{ }$ & & & & & & $\sqrt{ }$ & \\
\hline Supplier systems, engagement & & & & & & & & $\sqrt{ }$ & & & & \\
\hline Stakeholder/community focus groups & & & & $\sqrt{ }$ & $\sqrt{ }$ & $\sqrt{ }$ & $\sqrt{ }$ & & $\sqrt{ }$ & & $\sqrt{ }$ & \\
\hline $\begin{array}{l}\text { One-on-One stakeholder } \\
\text { meetings/consultations, } \\
\text { communication }\end{array}$ & & $\sqrt{ }$ & & $\sqrt{ }$ & & $\sqrt{ }$ & $\sqrt{ }$ & & $\sqrt{ }$ & & & \\
\hline Sustainability committee, team & & & & & & & & & & & $\sqrt{ }$ & \\
\hline \multicolumn{13}{|l|}{ Information Requests/RFP } \\
\hline Targets, Results & & & & & $\sqrt{ }$ & & & & & & $\sqrt{ }$ & \\
\hline $\begin{array}{l}\text { Social/environmental programs, } \\
\text { projects }\end{array}$ & & $\sqrt{ }$ & & & & $\sqrt{ }$ & $\sqrt{ }$ & & $\sqrt{ }$ & & & \\
\hline Corporate Sustainability Department & & & & & & & & & & $\sqrt{ }$ & & \\
\hline Partnerships & & & & & $\sqrt{ }$ & & & $\sqrt{ }$ & & & & \\
\hline Compliance reporting & $\sqrt{ }$ & $\sqrt{ }$ & $\sqrt{ }$ & $\sqrt{ }$ & $\sqrt{ }$ & $\sqrt{ }$ & $\sqrt{ }$ & $\sqrt{ }$ & $\sqrt{ }$ & & & \\
\hline $\begin{array}{l}\text { Social/environmental impact } \\
\text { assessments }\end{array}$ & & $\sqrt{ }$ & $\sqrt{ }$ & $\sqrt{ }$ & $\sqrt{ }$ & $\sqrt{ }$ & & $\sqrt{ }$ & & & & \\
\hline Community open days/events & & & & & & & & & & & & \\
\hline
\end{tabular}


Table Four: Discursive and Material Practices of those with wide interactions

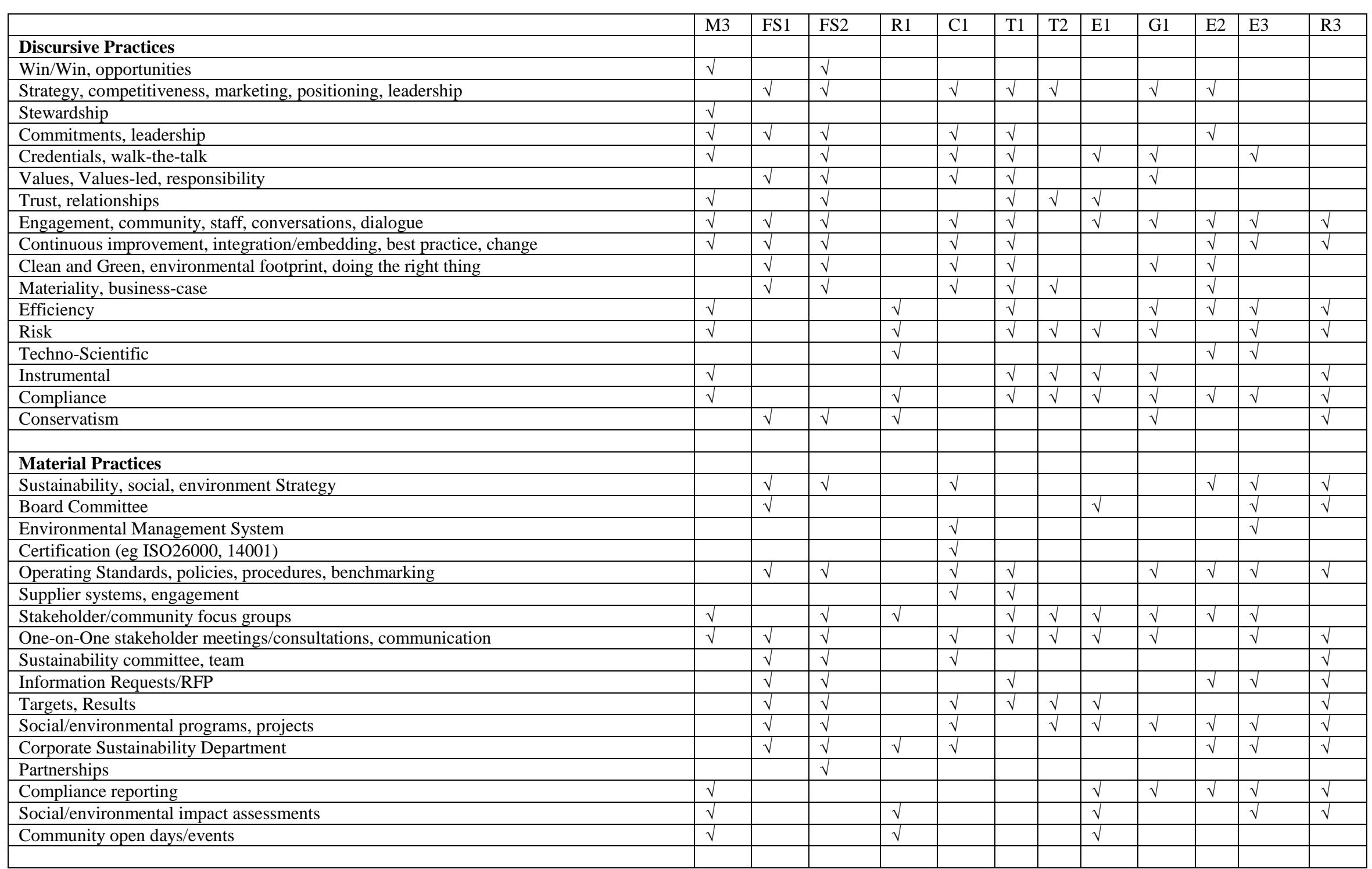

